$3(30) / 2015$

\author{
Wojciech Siegień \\ Uniwersytet Gdański \\ w.sehen@gmail.com
}

\title{
Pisarstwo i masochizm Jana Jakuba Rousseau
}

\section{Summary \\ The writing and masochism of Jean-Jacques Rousseau}

The present paper is an attempt at discursive exercises involving the application of modern psychiatric knowledge, treated as a variant of truth-discourse about human sexuality, for the diagnosis of the mental condition of Jean-Jacques Rousseau. An analysis of his "Confessions" shows that in his case one can speak of a strong masochistic tendency. Masochism is analyzed not only in the context of sexual paraphilia. Equally important is proximity of masochistic tendencies and gestures to record his own confessions.

Słowa kluczowe: Rousseau, masochizm, pisarstwo, sadyzm, literatura

Keywords: Rousseau, masochism, writing, sadism, literature

\section{Wstęp}

W historii literatury polskiej są przykłady tłumaczeń z języków obcych oraz komentarzy do nich, które same w sobie stanowią wartościowe dzieła. Niekiedy lektura wstępu autorstwa tłumacza może konkurować pod względem literackim z samym oryginałem. W moim odbiorze jest tak z „Wyznaniami” Jana Jakuba Rousseau w przekładzie Tadeusza Boya-Żeleńskiego. W słowie od tłumacza Boy-Żeleński ocenia, że pisma filozoficzne Rousseau „spoczywają w pyle zapomnienia”. Jest jednak książka, która oparła się próbie czasu i współcześnie (dla Boya) pozostaje interesująca i żywa. Mowa oczywiście o „Wyznaniach” Jana Jakuba Rousseau. Boy-Żeleński pozostaje pod dużym wrażeniem pierwszych, słynnych słów, którymi Rousseau rozpoczyna swoją autobiografię: „Imam się przedsięwzięcia, które dotychczas nie miało przykładu i nie będzie miało naśladowcy” (Rousseau 1978: 63). Tłumacz komentuje: „Ani przed nim, ani po nim, odkąd istnieje literatura, nikt nie obnażył w ten sposób swojego wnętrza. Mimo iż właśnie wpływ Russa rozpętał orgie wystawiania na pokaz swojego ,ja”, (...) w literaturze XIX wieku nikt nie dorównał mu co do bezwzględności w bezwstydzie" (Boy-Żeleński w: Rousseau 1978: XIV).

Boy-Żeleński pisał te słowa w 1917 roku i dlatego mógł nie wiedzieć, że się myli. Dopiero za kilkanaście lat od tego momentu Maurice Heine skompletował ostateczny tekst „120 dni Sodomy” markiza de Sade. W tym dziele, napisanym w końcu XVIII wieku, poziom bezwzględności bezwstydu podniesiony został do niewyobrażalnych przedtem 
rozmiarów. Znacząco wcześniej, bo jeszcze w 1870 roku opublikowano „Wenus w futrze” Leopolda Sacher-Masocha. Ta książka została przetłumaczona na język polski dopiero w 1920 roku.

\section{Założenia}

Boy-Żeleński mógł mylić się jeszcze w jednym. Rousseau nie był tym, który rozpętał orgię ekshibicjonizmu, która miała wybuchnąć w XIX wieku. Było dokładnie inaczej. Rousseau pod tym względem był raczej sumiennym uczniem swoich czasów. Żeby to wyjaśnić, proponuję spojrzeć na „Wyznania” przez pryzmat tez zawartych w „Historii seksualności” Michela Foucaulta (2000). Tam Foucault rozważa istnienie pewnego nakazu dyskursywnego, wyraźnego w kulturze Zachodu już od XVII wieku.

Co to był więc za nakaz, który obowiązywał np. mieszkańców Paryża na długo przed pojawieniem się w nim Rousseau? To było „niekończące się zadanie mówienia, mówienia samemu sobie, a także komuś innemu wszystkiego, co może dotyczyć gry przyjemności, doznań i nieprzeliczonych myśli, które przez dusze i ciało spokrewnione są jakoś z seksem" (Foucault 2000: 25). Ten nakaz to nic innego, jak projekt dyskursywizacji seksu, ukształtowany dawniej, jeszcze $\mathrm{w}$ średniowieczu w praktykach klasztornych i ascetycznych, a od XVII wieku upowszechniony na wszystkich. Specyficzną synekdochą tego zjawiska był i pozostaje dyskursywny gest ,wyznania”. Dawniej było to wyznanie winy podczas aktu spowiedzi, podczas gdy w XX wieku akt wyznania może odbywać się także na psychoanalitycznej kozetce. Niemniej tak produkowała się według Foucaulta "prawda” o seksie, albo inaczej: scientia sexualis. Pokrótce można powiedzieć, że nauka o seksualności lawinowo rozwijana od końca XIX wieku, była wyrazem zachodniej woli wiedzy o seksie. Ta wola wiedzy realizowała się najpełniej poprzez procedury i formy naukowe. Stąd Foucault pisze o mechanizmach unaukowienia tradycyjnego wyznania. Te mechanizmy, zrodzone na przełomie XIX i XX wieku, dają się obserwować do dziś. Z jednej strony jest to tendencja do tworzenia klinicznych klasyfikacji form diagnozy wyznania od wywiadu klinicznego, poprzez kwestionariusze ankiet itp. Z drugiej, jest to mechanizm przypisujący różnym typom zaburzeń, np. zaburzeniom rozwojowym dzieci czy nerwicom dorosłych, etiologię o naturze seksualnej. Foucault nazywał to zasadą seksu jako przyczyny wszystkiego i czegokolwiek (Foucault 2000: 64). Seksualność zostaje także przemieszczona i staje się utajniona. Nie wystarczy opowieść o przeżyciu seksualnym, bo jego istota jest mroczna, trudno dotrzeć do właściwej prawdy o nim. Dlatego tylko metodyczna, naukowa praca nad wyznaniem może pomóc w dotarciu do utajnionych (podświadomych?) treści seksualnych. Ta metodyczna praca nad wyznawaniem i odbiorem wyznania rodzi coś, co można by nazwać relacją kliniczną. Prawda o problemie nie leży już tylko w podmiocie wyznającym. Prawda wyłania się z relacji klinicznej i dopełnia się w czynności interpretacji wyznania. Słuchający, uzbrojony w techniki rozszyfrowuje prawdę o seksualności wyznającego, wpisując je w naukowe ramy interpretacji. $\mathrm{W}$ ten sposób seksualność przestaje przynależeć do sfery moralnej - grzechu, a staje się częścią 
systemu dzielącego zachowania na normalne i patologiczne, zdrowe i chore. Tak więc dawne wyznanie staje się częścią systemu psychiatrii i centralnym elementem techniki terapeutycznej, funkcjonującym w podobnym znaczeniu także w dzisiejszej praktyce psychoterapeutycznej: ,prawda - wypowiedziana na czas, komu trzeba i przez kogo trzeba, kto ją posiada i ponosi za nią odpowiedzialność - uzdrawia” (Foucault 2000: 65).

Celem mojej pracy będzie zatem przeprowadzenie dyskursywnego ćwiczenia, które ma polegać na zastosowaniu nowoczesnych wytworów jednego z wariantów prawdziwościowego dyskursu o ludzkiej seksualności, do postawienia diagnozy Janowi Jakubowi Rousseau1. Mówiąc o prawdziwościowym dyskursie o seksualności, mówię o dyskursie psychiatrycznym. Medycyna psychiatryczna, korzeniami sięgająca pracy Richarda Kraffr-Ebinga „Psychopathia Seksualis” z 1886 roku, może być uważana za współczesną nam wersję scientia sexualis (patrz szerzej: Foucault 2000: 52-71). Najprościej rzecz ujmując, chodzi mi o odpowiedź na pytanie: Jaki rodzaj zaburzenia psychicznego można by zdiagnozować u Jana Jakuba Rousseau z perspektywy dzisiejszej wiedzy psychiatrycznej, a szerzej - wiedzy dotyczącej perwersji seksualnych? Dodatkowo, zadaję sobie pytanie o relację ewentualnej patologii seksualnej z byciem autorem tekstów, czyli: W jaki sposób można połączyć specyfikę perwersji Rousseau z jego działalnością pisarską?

Foucault kreśli prostą linię, wiodącą od tych siedemnastowiecznych, a może i wcześniejszych praktyk duszpasterskich opartych na wyznaniu, do ich projekcji na literaturę - a szczególnie literaturę skandaliczną. W tym kontekście Foucault przywołuje dzieło markiza de Sade’a pisząc: „historia nowożytnej seksualności wykształciła się w znacznej mierze wraz z chrześcijańskim duszpasterstwem” (Foucault 2000: 26). To, czym różniło się działanie duszpasterskie od gestu pisarskiego ekshibicjonizmu - żeby zastosować powiedzenie Boya - to przede wszystkim cel tego wyznania. W pisaniu de Sade'a - ale jak zobaczymy - jeszcze silniej u Rousseau, chodziło raczej o spotęgowanie seksualnych doznań, a nie ich wygaszenie poprzez spowiedź. Spotęgowaniu ich służył dokładny opis wywrotowych praktyk seksualnych. Tekst stawał się przedłużeniem przeżyć erotycznych, ich powtórzeniem, a jednocześnie stymulatorem. To więc, co stanowiło najdobitniej o różnicy między obydwoma kontekstami gestu wyznania, to element perwersyjny, który zawiera się w czynności pisania, a następnie publikowania seksualnych wyznań. W przypadku de Sade'a, perwersja związana była dodatkowo z działaniem wywrotowym, transgresyjnym w stosunku do przyjętych społecznych ram moralnych. I to być może właśnie pisarstwo Sade'a po raz pierwszy w historii literatury dowodzi, że początkiem perwersyjnego aktu seksualnego (niech to będzie seksualna relacja sadystyczna) jest samo opowiadanie o nim. Jak pisze Elisabeth Roudinesco, perwersyjna transgresja realizuje się nie poprzez czyn, a poprzez pisanie o nim (Roudinesco 2009: 42-43).

\footnotetext{
1 Inspiracją dla tak ujętego celu pracy jest książka Andrzeja Ledera pt. „Prześniona rewolucja. Ćwiczenie z logiki historycznej".
} 


\section{Tekst „Wyznań”}

Rozpoczynając przegląd tekstu „Wyznań”, chcę zaznaczyć, uprzedzając dalsze rozumowanie, że w przypadku Jana Jakuba Rousseau i z punktu widzenia stanu obecnej wiedzy psychiatrycznej, mamy z cała pewnością do czynienia z perwertem. W przeglądzie jego autobiografii użyję więc słownika specyficznego dla opisu psychopatologii.

Rousseau „Wyznania” nazywa swoją spowiedzią i rozpoczyna słynnymi słowami, pełnymi poczucia patologicznej omnipotencji oraz wielkościowego narcyzmu: „Imam się przedsięwzięcia, które dotychczas nie miało przykładu i nie będzie miało naśladowcy. Chcę pokazać moim bliźnim człowieka w całej prawdzie jego natury; a tym człowiekiem będę ja” (Rousseau 1978: 3). Dalej następuje opis wczesnych etapów życia autora. Na podstawie lektury możemy stwierdzić, że przyjście na świat Jana Jakuba było związane z silną traumą w podwójnym znaczeniu. Po pierwsze, podczas porodu umiera jego matka. To pierwotna trauma. Po drugie, jako noworodek Rousseau jest w ciężkim stanie i tylko dzięki szczęśliwemu zbiegowi okoliczności udaje mu się przeżyć. Doświadczenie kliniczne podpowiada, że taka podwójna trauma związana z zagrożeniem życia matki i dziecka, która dodatkowo blisko sąsiaduje z momentem inicjacji życia, może mieć silny wpływ na późniejszy rozwój dziecka. I tak było w tym przypadku.

Dla postawienia pełnej diagnozy ważny jest pewien epizod z życia ośmioletniego Rousseau, który nazywany jest epizodem złamanego grzebienia panny Lembercier (Stelzig 2000: 61). W owym czasie chłopiec znajdował się pod opieką swojego wuja, pastora Jeana Jacques'a Lamberciera i mieszkał na wsi niedaleko Genewy. W „Wyznaniach” ten etap życia na wsi autor opisuje jako sielankę. W imieniu pastora Lambercier bezpośrednią opieką nad Rousseau i jego kuzynem zajmowała się panna Lembercier - Rousseau uważał ją prawie za matkę. Opiekunka, choć oddana opiece nad chłopcami, na krnąbrność dzieci reagowała czasem groźbami kary. Incydentalnie wprowadzała groźby w życie, co mogło oznaczać dotkliwą karę dla dzieci. Rousseau wspomina jednak swoją dziecięcą reakcję na wymierzaną mu karę w sposób przewrotny i nieoczekiwany. Przywołując swoje przeżycia jako dziesięciolatka, zadziwia: „Trzeba było nawet całej szczerości tego przywiązania i wrodzonej mej łagodności, żeby mnie powstrzymać od pokusy powtórnego zasłużenia na tę karę. W tym bólu bowiem, we wstydzie nawet, znalazłem domieszkę zmysłowej rozkoszy, której wspomnienie, silniejsze od obawy, budziło we mnie raczej chęć doznania jeszcze raz tych samych wzruszeń z tej ręki” (Rousseau 1978: 16). W tym zdaniu Rousseau łączy w jeden uczuciowy konglomerat takie swoje uczucia, jak ból (fizyczny), wstyd i rozkosz. Wszystkie przypomina sobie jako rodzące się w dziecięcej reakcji na karcenie ze strony ukochanej osoby, kobiety-piastunki.

Rousseau sam widzi w tym doświadczeniu niejako wzór dla dalszego rozwoju swojego popędu seksualnego. My, uzbrojeni w terminologię psychoanalityczną, moglibyśmy powiedzieć, że w tym okresie i pod wpływem podobnego doświadczenia u młodego chłopca zachodzi jakiegoś rodzaju nieprawidłowa kateksja libidinalna, wyrażająca się w zainteresowaniu - w swojej istocie erotycznym - osobą opiekunki (Moore, Fine 1996: 121). 
Rousseau sam opisuje ten moment następująco: „Z krwią przepaloną zmysłami niemal od urodzenia uchowałem się czysty od zmazy do wieku, w którym najzimniejsze i najbardziej spóźnione temperamenty przychodzą do głosu. Dręczony długo sam nie wiedząc czym, pożerałem płomiennym wzrokiem piękne kobiety; wyobraźnia moja przyzywała je nieustannie jedynie po to, aby im kazać działać w myśl moich upodobań i wskrzeszać pod ich postacią pannę Lambercier i jej egzekucję" (Rousseau 1978: 17). Można więc powiedzieć, że Rousseau otwarcie przyznaje, że doświadczenie kary ze strony piastunki stało się dla niego punktem fiksacji. Wyobraźnia zaś stała się dla niego tym polem, na którym na nowo planował i odgrywał moment upokorzenia i wstydu. Zapisane strony „Wyznań” stały się więc pierwszym miejscem ujawnienia tych dziecięcych fantazji - ich materializacji w sensie dosłownym.

W okresie dojrzewania i dorosłości ta seksualna preferencja utrwaliła się. W „Wyznaniach” czytamy o tym tak: „W ten sposób przeżyłem życie pożądając i ukrywając moje pożądania przy boku osób, które kochałem najwięcej. Nie śmiejąc nigdy wyznać mych upodobań, oszukiwałem je bodaj, dając stosunkom moim formy pokrewne. Przebywać u kolan despotycznej kochanki, ulegać jaj rozkazom, żebrać przebaczenia - było dla mnie najsłodszą rozkoszą; im bardziej rozpalona wyobraźnia smagała mi krew, tym bardziej na zewnątrz miałem postać trwożnego wielbiciela" (Rousseau 1978: 19). Z tego zwierzenia dowiadujemy się, że we wczesnym okresie dorosłości fantazje Rousseau pozostawały niezrealizowane i wciąż rozgrywały się na poziomie wyobraźni. Czyniąc te wyznanie, Rousseau dąży jednak do czegoś innego niż czysty ekshibicjonizm. Spowiedź przed czytelnikiem i odkrycie przed nim swoich perwersji Rousseau chce uczynić dowodem swojej niewinności i czystości: „Oto moje zmysły, jednocząc się z nieśmiałym usposobieniem i romantyczną głową, zachowały mi czystość uczuć i skromność obyczajów" (Rousseau 1978: 19). Wybawieniem przed „zezwierzęceniem” stała się dla niego wrodzona nieśmiałość, przy czym fantazje erotyczne zdawały się pełnić w ciągu całego życia rolę kompensacyjną w stosunku do niezrealizowanego popędu. Część „Wyznań”, jak ją sam nazywa - najtrudniejszą, bo związaną z wyznaniem dotyczącym transgresywnych tendencji seksualnych - Rousseau kończy krótkim zdaniem: „Zdarzyło mi się to raz tylko, w dzieciństwie, z dziewczyną w moim wieku, a i wówczas propozycja wyszła raczej od niej" (Rousseau 1978: 21-22). To zwierzenie nie zostało skomentowane.

\section{Diagnoza}

Rousseau swoje tendencje seksualne interpretował w kategoriach wstydu, śmieszności, ogólnie rozumianego pojęcia szaleństwa zmysłów, za które odpowiadał taki a nie inny jego temperament. Po stu latach od zapisu tych wyznań symptomy opisywane przez Rousseau zostały zdefiniowane na nowo, w języku tworzącej się wtedy psychiatrii. W 1886 roku ukazała się klasyczna pozycja Richarda Krafft-Ebinga pt. „Psychopatia sexualis”. Katalogowała ona po raz pierwszy zaburzenia seksualne i to właśnie Krafft-Ebing zamieścił tam nową jednostkę chorobową - masochizm. Dzieło Krafft-Ebinga na długi czas 
stało się źródłem pojęć wykorzystywanych w diagnozie zaburzeń seksualnych. W odniesieniu do Rousseau z dużą dozą pewności można by postawić właśnie diagnozę masochizmu. O czym więc mówimy, gdy mówimy dzisiaj o masochizmie?

Po pierwsze, dziś wyróżnia się masochizm moralny jako nieświadome dążenie do cierpienia (Bonnet 2006: 62). Zalicza się je do cech osobowościowych. Podstawowymi przejawami tak ukształtowanej osobowości są potrzeba otrzymywania kary, poczucie bycia nieszczęśliwym czy przeżywanie cierpienia duchowego. Takie uczucia stanowią ważną część bycia człowieka w sobie lub inaczej - jego tożsamości. Źródłem satysfakcji dla masochisty jest choroba i cierpienie. Niektórzy psychoanalitycy uważają, że jest to nawyk psychiczny, sytuujący się pomiędzy nerwicą a perwersją. Jeśli jednak podobne tendencje realizują się na poziomie erotycznym, to mamy do czynienia z perwersją seksualną. Trzeba pamiętać, że masochizm jest blisko połączony z sadyzmem. Łączy je poszukiwanie podobnych uczuć - cierpienia, bólu, poniżenia (Freud 1999: 52-55). Na marginesie warto dodać, że część takich tendencji może realizować się poprzez praktyki ascetyczne i mistyczne. W tym sensie rozważania o perwersjach łączą się z wcześniejszymi rozważaniami dotyczącymi ewolucji gestu wyznania od średniowiecza do wieku XX. Tę intuicję najlepiej oddaje powieść Aldousa Huxleya „Diabły z Loudun” (2010).

\section{Perwersja a literatura}

W kontekście „Wyznan” i postawionych sobie pytań chcę zwrócić uwagę na pewien element masochizmu, który nie jest powszechnie znany. Otóż masochizm, jak i sadyzm blisko łączą się z funkcją wydalania. Psychoterapeuci o orientacji psychoanalitycznej wielokrotnie podkreślali związek między wydalaniem i pisaniem perwersyjnej literatury, a szerzej między pisaniem po papierze i ,pisaniem” po ciele (Bonnet 2004: 65-66). Co to oznacza? Rzecz w tym, że impuls do utrwalania w piśmie swoich przeżyć pozwala sądzić, że zarówno sadysta, jak i masochista poszukują przede wszystkim solidnej i trwałej formy ekspresji, aby utrwalić to, co wyraża ich pragnienia, w taki sposób, aby móc się do tego odwołać. W związku z powyższym staje się jasne, dlaczego tylko te perwersje mają nazwy utworzone od nazwisk pisarzy, którzy w jakimś stopniu zrealizowali te zamierzenia: Markiza de Sade i Leopolda von Sacher-Masocha.

Ta intuicja psychoanalityczna, łącząca sadomasochizm z pisarstwem, została podtrzymana i rozwijana przez współczesny dyskurs humanistyczny, który na własną rękę poszukiwał połączenia pomiędzy perwersją sadomasochistyczną a pisaniem jako elementem podtrzymywania perwersyjnych doświadczeń. Wydaje się, że najpełniejszej analizy transgresji seksualnej dokonał George Bataille. Moje rozważania nawiązują do tych wątków jego prac, w których analizuje semantyczne nici łączące erotyzm, rozumiany jako poszukiwanie szczęścia i rozkoszy, z przerażeniem lub trwogą (Bataille 1992: 82-100; Bataille 2008: 135-159). Batallie twierdzi, że przerażenie odgrywa bardzo ważną rolę w przyciąganiu erotycznym. I nie jest to wcale paradoks. Sednem Batallie'owskiego rozumienia przerażenia, jako powiązanej z erotyzmem reakcji, jest zanegowanie pewnego 
zdroworozsądkowego rozumowania. Większość z nas jest gotowa przecież zgodzić się, że przerażenie wywołują $\mathrm{w}$ nas bodźce zagrażające nam. Przerażeniem reagujemy też na sytuacje, w których nasza tożsamość, być może dotąd dobrze zintegrowana, nagle staje się chwiejna. Batallie nie daje się jednak zwieść zdrowemu rozsądkowi lub poprawnemu osądowi myślowemu i rozumuje poza zasadą przyjemności. Według niego reakcja przerażenia jest w zasadzie mechanizmem motywacyjnym, który sprzyja erotyzacji obiektów wywołujących w nas przerażenie. Według jego słów: „Pragniemy czegoś, co wyczerpuje nasze siły i zasoby oraz - jeśli trzeba - naraża na niebezpieczeństwo nasze życie" (Bataille 2008: 137). Nie zapominajmy, że jest to pragnienie ze swej natury transgresyjne.

Dobrym przykład odejścia od zdroworozsądkowego myślenia jest połączenie literatury i fikcji literackiej właśnie z poszukiwaniem przeżyć przerażających. Batallie pisze: „Atrakcyjność powieści wiąże się z nieszczęściami przydarzającymi się bohaterowi. (...) wolne od trudności i lęków, jego życie nie miałoby w sobie nic, co mogłoby nas fascynować i zmusić do przeżywania wraz z nim” (Bataille 2008: 139). W odniesieniu do „Wyznań” Rousseau warto podkreślić, że powieściowa fikcja pomaga znosić to, co przeniesione w sferę rzeczywistości mogłoby się okazać ponad nasze siły i nas przytłoczyć (Bataille 2008: 139). W literackiej fikcji, tak jak Rousseau w swoich fantazjach, możemy przeżyć to wszystko, na co nie moglibyśmy się zdecydować w życiu realnym. Nieodłącznie z tym przeżywaniem łączy się element masochistyczny - satysfakcjonujący odbiór fikcji to taki, który potrafi „czerpać przyjemność ze związanego z nim odczucia utraty bądź zagrożenia” (Bataille 2008: 139).

\section{Konkluzja}

Można powiedzieć, opierając się na refleksjach Bataille’a, że jako odbiorcy zafascynowani fikcją literacką w istocie rzeczy realizujemy rudymentarną dla człowieka perwersję o podłożu masochistycznym. Fikcja literacka (podobnie zresztą jak religijna ofiara) przybliża nas na chwilę do śmierci, jednocześnie zapowiadając radość - bo tylko warunek uniknięcia śmierci - tak w obrzędzie ofiarnym (śmierć i zmartwychwstanie) lub w fikcji, daje możliwość odczucia oczekiwanej, finalnej radości. To Battaille’owskie ujęcie to nic innego, jak sadomasochistyczna wizja fikcji literackiej oraz religii i terapii - jako jej mutacji. W odniesieniu do diagnozy postawionej w tekście Rousseau można powiedzieć, że pisząc swoje „Wyznania”, zrealizował on masochistyczną potrzebę utrwalenia swojego perwersyjnego pożądania i świadomie wystawił się na krytyczny osąd czytelnika. Jednak Freud przestrzegał nas, że masochizm łączy się z sadyzmem. Z drugiej strony więc my, jako czytelnicy jego literatury, stajemy się poszukiwaczami opisu transgresji. Jako odbiorcy jego wyznania upadku moralnego dajemy się uwieść przerażeniu, żeby poczuć się w końcu lepszymi. Rousseau to wiedział, gdy w swojej inwokacji do czytelników przewidywał ich reakcję i to, że ktoś po lekturze powie: Byłem lepszy od tego człowieka. Być może tego rodzaju poniżenia Rousseau także poszukiwał. Błędne koło masochizmu. 


\section{Literatura}

Bataille G. (1992), Literatura a zło. Kraków, Oficyna Literacka.

Bataille G. (2008), Historia erotyzmu. Warszawa, Wydawnictwo Aletheia.

Bonnet G. (2006), Perwersje seksualne: historia pojęcia, opis objawów, przyczyny. Gdańsk, GWP. Foucault M. (2000), Historia seksualności. Warszawa, Wydawnictwo Czytelnik.

Freud S. (1999), Życie seksualne. Warszawa, Wydawnictwo KR.

Huxley A. (2010), Diably z Loudun. Warszawa, PIW.

Leder A. (2014), Prześniona rewolucja. Ćwiczenie z logiki historycznej. Warszawa, Krytyka Polityczna.

Moore B.E., Fine B.D. (1996), Słownik psychoanalizy. Warszawa, Jacek Santorski \& Co.

Rosenhan D.L., Seligman M.E.P. (1994), Psychopatologia, Warszawa, Polskie Towarzystwo Psychologiczne.

Roudinesco E. (2009), Nasza ciemna strona. Z dziejów perwersji. Warszawa, Wydawnictwo Czytelnik

Rousseau J.J. (1978), Wyznania. Wrocław, Zakład Narodowy im. Ossolińskich.

Stelzig E.L. (2000), The Romantic Subject in Autobiography: Rousseau and Goethe. Charlottesville, University of Virginia Press. 